\title{
Role of angiogenesis and angiogenic factors in acute and chronic wound healing
}

\author{
Thittamaranahalli Muguregowda Honnegowda', Pramod Kumar ${ }^{1,2}$, \\ Echalasara Govindarama Padmanabha Udupa ${ }^{3}$, Sudesh Kumar ${ }^{4}$, Udaya Kumar ${ }^{4}$, Pragna Rao ${ }^{3}$
}

${ }^{1}$ Department of Plastic Surgery and Burns, Kasturba Medical College, Manipal 576104, Karnataka, India.

${ }^{2}$ Department of Plastic Surgery, King Abdulaziz Specialist Hospital, Sakaka 42421, Al-Jouf, Saudi Arabia.

${ }^{3}$ Department of Biochemistry, Kasturba Medical College, Manipal 576104, Karnataka, India.

${ }^{4}$ Department of Surgery, District Government Hospital, Udupi 576108, Karnataka, India.

Address for correspondence: Dr. Pramod Kumar, Department of Plastic Surgery and Burns, King Abdulaziz Specialist Hospital, Sakaka 42421, Al-Jouf, Saudi Arabia. E-mail: pkumar86@hotmail.com

\begin{abstract}
Angiogenesis plays a crucial role in wound healing by forming new blood vessels from preexisting vessels by invading the wound clot and organizing into a microvascular network throughout the granulation tissue. This dynamic process is highly regulated by signals from both serum and the surrounding extracellular matrix environment. Vascular endothelial growth factor, angiopoietin, fibroblast growth factor and transforming growth factor-beta are among the potent angiogenic cytokines in wound angiogenesis. Specific endothelial cell ECM receptors are critical for morphogenetic changes in blood vessels during wound repair. In particular integrin $(\alpha v \beta 3)$ receptors for fibrin and fibronectin, appear to be required for wound angiogenesis: $\alpha v \beta 3$ is focally expressed at the tips of angiogenic capillary sprouts invading the wound clot, and any functional inhibitors of $\alpha v \beta 3$ such as monoclonal antibodies, cyclic RGD peptide antagonists, and peptidomimetics rapidly inhibit granulation tissue formation. In spite of clear knowledge about influence of many angiogenic factors on wound healing, little progress has been made in defining the source of these factors, the regulatory events involved in wound angiogenesis and in the clinical use of angiogenic stimulants to promote repair.
\end{abstract}

Key words:

Angiogenic factors, endothelium, extracellular matrix protein, granulation tissue, wound healing

\section{INTRODUCTION}

Neovascularization or angiogenesis is important for wound healing as it involves the growth of new capillaries to form granulation tissue..$^{[1-4]}$ Three to five days after tissue injury, new capillaries become visible in the wound bed as granulation tissue, which acts as a matrix for proliferating blood vessels, migrating fibroblasts and new collagen. ${ }^{[5]}$ Impaired granulation is a hallmark of chronic wounds encountered with diabetes and venous or arterial insufficiency.

\begin{tabular}{|l|l|}
\hline \multicolumn{2}{|c|}{ Access this article online } \\
\hline Quick Response Code: & Website: \\
\hline & www.parjournal.net \\
\hline & \\
\hline
\end{tabular}

In 1960s, research began in the field of angiogenesis to determine how new blood vessels enhance solid tumor growth. ${ }^{[6]}$ Physiologists later discovered that neovascularization occurs during tissue regeneration. ${ }^{[7]}$ Proliferating capillaries bring oxygen and micronutrients to growing tissues and remove catabolic waste products. These vessels are present in the endothelium that secretes paracrine factors to promote survival of adjacent cells by preventing apoptosis or programmed cell death. ${ }^{[8]}$ Because

This is an open access article distributed under the terms of the Creative Commons Attribution-NonCommercial-ShareAlike 3.0 License, which allows others to remix, tweak, and build upon the work non-commercially, as long as the author is credited and the new creations are licensed under the identical terms.

For reprints contact: reprints@medknow.com

How to cite this article: Honnegowda TM, Kumar P, Udupa EG, Kumar S, Kumar U, Rao P. Role of angiogenesis and angiogenic factors in acute and chronic wound healing. Plast Aesthet Res 2015;2:243-9.

Received: 20-10-2014; Accepted: 28-01-2015 
angiogenesis is required for wound healing, its induction is beneficial in many clinical situations for achieving wound closure.

\section{PHYSIOLOGICAL CONTROL OF ANGIOGENESIS}

Angiogenesis plays a critical role in wound healing. By developing capillary sprouts, which digest endothelial cells and invade the extracellular matrix (ECM) stroma after penetrating through the underlying vascular basement membrane (VBM), and form tube-like structures that continue to extend, branch, and form networks. During angiogenesis capillary advancement in ECM occurs by endothelial cell proliferation and direction of growth is guided by chemotaxis from the target region. The interaction among endothelial cells, angiogenesis factors and surrounding ECM proteins is temporally and spatially synchronized..$^{[9,10]}$

Angiogenesis can be induced in response to injury via pro- and anti-angiogenic factors present throughout the body. Pro-angiogenic factors consist of thrombin, fibrinogen fragments, thymosin- $\beta 4$ and growth factors. Angiogenic growth factors are stored in platelets and inflammatory cells that circulate in the bloodstream, and are sequestered within the ECM. The production of these factors is regulated by genes expressed in response to hypoxia and inflammation, such as hypoxia-inducible factors (HIF) and cyclooxygenase-2 (COX-2). ${ }^{[1-13]}$ In contrast, angiogenesis inhibitor factors suppress blood vessel growth. ${ }^{[14,15]}$ Some inhibitors circulate in the blood stream at low physiological levels while others are stored in the ECM surrounding blood vessels. Vascular growth is suppressed when there is a physiological balance between angiogenesis stimulators and inhibitors. ${ }^{[15]}$ Immediately following injury, however, angiogenic stimuli are released into the wound bed, and a shift occurs in regulators favoring vascular growth [Figure 1].

\section{THE ANGIOGENESIS CASCADE}

Angiogenesis occurs as an orderly cascade of molecular and cellular events in the wound bed:

1. Endothelial cell surface has receptors to which angiogenic growth factors bind in preexisting venules (parent vessels);

2. Growth factor-receptor binding activates signaling pathways within endothelial cells;

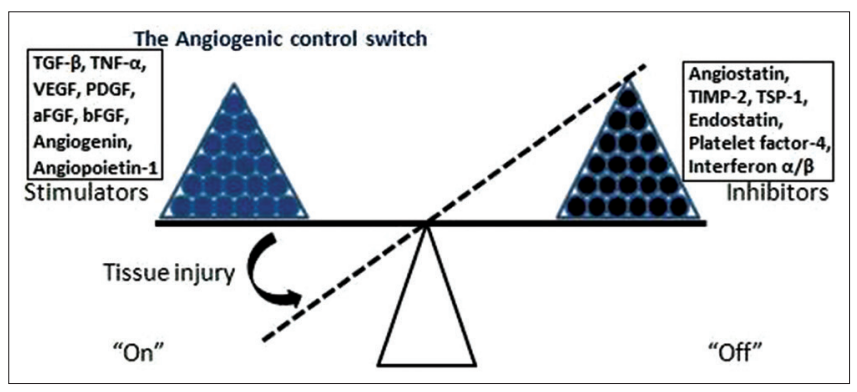

Figure 1: Angiogenesis is a balance between stimulators (growth factors) and inhibitors as shown in this model
3. Proteolytic enzymes released by activated endothelial cells dissolve the basement membrane of surrounding parent vessels;

4. Endothelial cells proliferate and sprout outward through the basement membrane;

5. Endothelial cells migrate into the wound bed using integrins $(\alpha v \beta 3, \alpha v \beta 5$ and $\alpha v \beta 1)$ which are cell surface adhesion molecules;

6. Matrix metalloproteinases (MMPs) dissolve the surrounding tissue matrix in the path of sprouting vessels;

7. Vascular sprouts form tubular channels that connect to form vascular loops;

8. Vascular loops differentiate into afferent (arterial) and efferent (venous) limbs;

9. New blood vessels mature by recruiting mural cells (smooth muscle cells and pericytes) to stabilize the vascular architecture;

10. Blood flow begins in the mature stable vessel.

These complex growth factor-receptor, cell-cell and cell-matrix interactions characterize the angiogenesis process, regardless of the stimuli or its location in the body.

\section{THE ANGIOGENESIS MODEL OF WOUND HEALING}

Wound healing occurs in four major overlapping stages: (1) hemostatic, (2) inflammatory stage, (3) proliferative stage, and (4) remodeling stage. Although granulation is assigned to the proliferative stage, angiogenesis is initiated immediately after tissue injury and is mediated throughout the wound healing process.

\section{Step I: Angiogenesis initiation}

Basic fibroblast growth factor (bFGF) stored within intact cells and the ECM is released from damaged tissue. ${ }^{[16]}$ Bleeding and hemostasis in a wound also initiate angiogenesis. Cellular receptors for vascular endothelial growth factor (VEGF) are upregulated by thrombin in the wound. ${ }^{[17]}$ Endothelial cells exposed to thrombin also release gelatinase A (MMP-2), which promotes the local dissolution of basement membrane, a necessary early step of angiogenesis. ${ }^{[18]}$ Platelets release multiple growth factors, including platelet-derived growth factor (PDGF), VEGF, transforming growth factor (TGF- $\alpha$, TGF- $\beta$ ), bFGF, platelet-derived endothelial cell growth factor and angiopoietin-1 (Ang-1). These factors stimulate endothelial proliferation, migration and tube formation. ${ }^{[19-22]}$

\section{Step 2: Angiogenesis amplification}

Macrophages and monocytes release numerous angiogenic factors, including PDGF, VEGF, Ang-1, TGF- $\alpha$, bFGF, interleukin-8 (IL-8) and tumor necrosis factor alpha into the wound bed during the inflammatory phase amplifying angiogenesis further. ${ }^{[23,24]}$ Several growth factors (PDGF, VEGF and bFGF) synergize in their ability to vascularize tissues. ${ }^{[25]}$ Proteases that break down damaged tissue matrix further release matrix-bound angiogenic stimulators. Enzymatic cleavage of fibrin yields fibrin fragment E, which stimulates angiogenesis directly and also enhances the 
effects of VEGF and bFGF.[26] Expression of the inducible COX-2 enzyme during the inflammatory stage of healing also leads to VEGF production and other promoters of angiogenesis. ${ }^{\mid 27]}$

\section{Step 3: Vascular proliferation}

Hypoxia is an important driving force for wound angiogenesis. Expression of gene HIF-1 $1 \alpha$, due to hypoxic gradient between injured and healthy tissue triggers VEGF production. ${ }^{[24,28]}$ VEGF is present in both wound tissue and exudate. ${ }^{[28,29]}$ VEGF is also known as vascular permeability factor since it increases permeability of capillaries. ${ }^{[30]}$ Hypoxia also leads to endothelial cell production of nitric oxide (NO). NO promotes vasodilation and angiogenesis to improve local blood flow. ${ }^{[31]}$

\section{Step 4: Vascular stabilization}

Vascular stabilization is governed by Ang-1, tyrosine kinase with immunoglobulin-like and EGF-like domains 2 (Tie-2), smooth muscle cells and pericytes. Production of PDGF and recruitment of smooth muscle cells and pericytes to the newly forming vasculature are regulated by binding of Ang- 1 to its receptor Tie- 2 on activated endothelial cells. $^{[32-34]}$ A PDGF deficiency leads to poorly-formed immature blood vessels. ${ }^{[35]}$

\section{Step 5: Angiogenesis suppression}

Angiogenesis is suppressed at the terminal stages of healing. ${ }^{[36]}$ As tissue hypoxia is restored, and inflammation subsides, the level of growth factors decline in the wound. Pericytes which stabilize endothelial cells secrete an inhibitory form of activated TGF- $\beta$ that impedes vascular proliferation. ${ }^{[34,37,38]} \mathrm{A}$ cleavage product of collagen XVIII, endostatin, is present surrounding the VBM, and it inhibits wound vascularity. ${ }^{[39,40]}$

\section{WOUND ANGIOGENIC STIMULATORS AND INHIBITORS}

A number of angiogenic stimulators have been identified in wound sand others are likely to exist that play an important role in the repair [Table 1]. The stimulators in wound fluids are growth factors known to increase endothelial cell migration and proliferation in vitro. ${ }^{[4]}$

The FGF comprises of 23 homologous structures that are small polypeptides with a central core containing

Table 1: Angiogenic stimulators and inhibitors

\begin{tabular}{ll}
\hline Stimulators & Inhibitors \\
\hline aFGF (FGF-1) & Thrombospondin-1 \\
bFGF (FGF-2) & Tissue inhibitors of matrix metalloproteinases \\
TGF- $\alpha$ & Interferon alpha/beta/gamma \\
TGF- $\beta$ & Angiostatin \\
PGE2 & Endostatin \\
TNF- $\alpha$ & \\
VEGF & \\
EGF & \\
\hline
\end{tabular}

FGF: Fibroblast growth factor, aFGF: Acidic fibroblast growth factor, bFGF: Basic fibroblast growth factor, TGF- $\alpha$ : Transforming growth factor-alpha, TGF- $\beta$ : Transforming growth factor-beta, VEGF: Vascular endothelial growth factor, EGF: Endothelial growth factor, PGE2: Prostaglandin E2
140 amino acids. Acidic FGF and bFGF are the first few to be discovered and are now designated as FGF-1 and FGF-2, respectively. ${ }^{[42]}$ Both are preferentially involved in the process of angiogenesis..$^{[43,44]}$ These compounds are polypeptides of about $18 \mathrm{kDa}$, single chained and nonglycosylated. They transmit their signals through FGF receptor-4 (FGFR-4) high-affinity, protein family of transmembrane tyrosine kinases (FGFR-1 to FGFR-4), that bind to different FGFs with different affinities. The strong interactions of FGF-1 and FGF-2 with glycosaminoglycans, such as heparin sulfate present in the ECM, ${ }^{[45]}$ makes the FGFs stable against thermal, proteolytic denaturation and limits its diffusibility. Thus, the ECM acts as a reservoir for pro-angiogenic factors. Most members of the FGF family act as a broad spectrum mitogen that stimulates the proliferation of mesenchymal cells of mesodermal origin, as well as ectodermal and endodermal cells.

FGF-1 and FGF-2 are synthesized by a variety of cell types including inflammatory cells and dermal fibroblasts that are involved in angiogenesis and wound healing. When liberated from ECM, they act on the endothelial cells in a paracrine manner, or when released by endothelial cell they act in an autocrine manner promoting cell proliferation and differentiation. During the formation of granulation tissue, FGF-2 promotes cell migration through surface receptors for integrins, which mediate the binding of endothelial cells to ECM..$^{[44]}$

Vascular endothelial growth factor increase vaso-permeability by increasing the fenestration and hydraulic conductivity. This allows leakage of fibrinogen and fibronectin, which are essential for the formation of the provisional ECM. ${ }^{[46-48]}$ The ECM is produced in large quantities by the epidermis during wound healing. ${ }^{\mid 49]}$ Low oxygen tension that occurs in tissue hypoxia is a major inducer of VEGF[50] and its receptors. ${ }^{[51]}$ Thus, cell disruption and hypoxia appear to be strong initial inducers of potent angiogenesis factors at the wound site. VEGF family currently includes VEGF-A, VEGF-B, VEGF-C, VEGF-D, VEGF-E and placental growth factor. ${ }^{[52]}$ VEGF-A is a homodimer glycoprotein whose subunits are linked by 2 disulfide bonds. VEGF-A is synthesized from internal rearrangements ("alternative splicing") of mRNA. Thus, there is the production of 7 isoforms with 121 to 206 amino acids. ${ }^{[53-55]}$ Among these, the VEGF121, VEGF165, VEGF189 and VEGF206 are the predominant isoforms. ${ }^{[56]}$ These isoforms show similar biological activities, but differ in their binding properties to heparin and ECM. ${ }^{[57]}$

Vascular endothelial growth factor is a potent vascular endothelial cell-specific mitogen that stimulates endothelial cell proliferation, microvascular permeability and regulates of several endothelial integrin receptors during sprouting of new blood vessels. ${ }^{[58]}$ Furthermore, VEGF also acts as a survival factor for endothelial cells by inducing the expression of an anti-apoptotic protein B-cell lymphoma 2. ${ }^{[59]}$

TGF- $\beta$ stimulates the formation of granulation tissue by acting as a chemoattractant for neutrophils, macrophages and fibroblasts. Hence, TGF- $\beta$ is an important modulator of angiogenesis during wound healing by regulating cell 
proliferation, migration, capillary tube formation and deposition of ECM. ${ }^{[60,61]}$

The angiopoietins are members of the VEGF family, which is largely specific for vascular endothelium. They include a naturally occurring agonist, Ang-1, and antagonist, Ang-2, both of which act by means of the Tie- 2 receptor. Two new angiopoietins, Ang-3 in mice and Ang-4 in humans, have been identified, but their function in angiogenesis is unknown. ${ }^{[62]}$

Mast cell tryptase, stored in granules of activated mast cells, is an additional angiogenesis factor that directly degrades the ECM components or release matrix-bound growth factors by its proteolytic activity, ${ }^{[63,64]}$ and acts indirectly by activating latent matrix metalloproteases. The addition of tryptase to microvascular endothelial cells cultured on a basement membrane matrix (matrigel) caused a marked increase in capillary growth. Furthermore, tryptase can induce endothelial cell proliferation in a dose-dependent manner, whereas specific tryptase inhibitors suppress the capillary growth. ${ }^{[65]}$

\section{IMPAIRED ANGIOGENESIS IN CHRONIC WOUNDS}

Angiogenesis is impaired in all chronic wounds leading to further tissue damage results from chronic hypoxia and impaired micronutrient delivery. Specific defects have been identified in diabetic ulcers, venous insufficiency ulcers and ischemic ulcers.

\section{Diabetic ulcers}

Patients with diabetes show abnormal angiogenesis in various organs. Vasculopathies associated with diabetes include abnormal blood vessel formation (e.g. retinopathy, nephropathy) and accelerated atherosclerosis leading to coronary artery disease, peripheral vascular disease, and cerebrovascular disease. ${ }^{[65]}$ However, in diabetics, angiogenesis is decreased ${ }^{[66]}$ resulting in poor formation of new blood vessels and thus decreased entry of inflammatory cells and their growth factors. Growth factors such as FGF-2 and PDGF, essential for wound healing have been found to be reduced in experimental diabetic wounds models. ${ }^{[67-70]}$ Furthermore, in rat models, topical administration of high glucose to wounds was shown to inhibit the normal angiogenic process,${ }^{[71]}$ suggesting a direct role for high glucose levels in diminished angiogenesis.

Vascular endothelial growth factor plays an important role in vascular growth and has been shown to be deficient in diabetic wounds in experimental and clinical models. ${ }^{[2]}$ Studies have shown that modulation of oxidative damage $e^{[73]}$ or inhibition of the receptors for advanced glycation end products ${ }^{[74]}$ improve wound healing and were associated with the up-regulation of endogenous VEGF. Moreover, VEGF administration improves wound healing in nondiabetic ischemic wounds ${ }^{[75]}$ and blocking VEGF with neutralizing antibodies impedes tissue repair. ${ }^{[76]}$ These studies support the notion that VEGF is critical for repair in impaired healing states and that the addition of VEGF could have a potential clinical use. ${ }^{[77]}$ In fact,
Galiano et al. ${ }^{[78]}$ found that topical VEGF accelerates wound healing in a diabetic mouse model.

Weinheimer-Haus et $a .^{[79]}$ found that low intensity vibration (LIV) applied vertically at $45 \mathrm{~Hz}$ with peak acceleration of $0.4 \mathrm{~g}$ for $30 \mathrm{~min}$ a day for 5 days a week starting on the day of injury in diabetic mice increases expression of pro-healing growth factors and chemokines (insulin-like growth factor-1, VEGF and monocyte chemotactic protein-1) in wound environment. Though there was no evidence of a change in the phenotype of $\mathrm{CD} 11 \mathrm{~b}+$ macrophages, however, LIV resulted in trend toward a less inflammatory phenotype in the CD11b2 cells which comprised of fibroblasts, endothelial cells and/or keratinocytes. These findings indicate that LIV may exert beneficial effects on wound healing by enhancing angiogenesis and granulation tissue formation, and these changes are associated with an increase in pro-angiogenic growth factors. ${ }^{\text {79] }}$

\section{Venous insufficiency ulcers}

Venous insufficiency ulcers or venous stasis ulcers result from incompetent valves in lower extremity veins, leading to venous stasis and hypertension that makes the skin susceptible to ulceration. Pathological findings associated with venous stasis ulcers include microangiopathy, fibrin "cuffing" and trapping of leukocytes within the microvasculature. ${ }^{[80,81]}$

Chronic venous stasis ulcer patients have elevated levels of VEGF in their circulation. ${ }^{[82]}$ This may explain the vascular permeability and increased transudation of serum fluid in their wounds. Biopsies of these ulcers reveal microvessels that are surrounded by fibrin cuffs composed of fibrin and plasma proteins, such as $\alpha$-macroglobulin, thought to compromise gas exchange. ${ }^{[83-85]}$ Clinical studies have shown that transcutaneous oxygen tension may be up to $85 \%$ lower in venous stasis ulcers compared with normal skin regions. ${ }^{[86]}$ VEGF expression is up-regulated by hypoxia, which further exacerbates vascular permeability, formation of pericapillary fibrin cuffs and compromised gas exchange, which ultimately reduces growth factor availability in the wound. ${ }^{87,88]}$ VEGF promotes the formation tortuous, aberrant glomeruloid-like vascular structures found in granulation tissue. ${ }^{[89]}$ Laboratory animals treated with VEGF form these glomeruloid vascular structures within 3 days and are characterized by poor perfusion..$^{[90]}$ In venous ulcers, the persistence of glomeruloid vessels may interfere with oxygen delivery and delay healing. In chronic venous stasis ulcers, high levels of proteases such as neutrophil elastase, MMPs and urokinase-type plasminogen activator are present. ${ }^{[1]}$ Concomitantly, there are decreased levels of protease inhibitors, such as plasminogen activator inhibitor-2. Excessive protease activity may degrade the growth factors and destroy granulation tissue.

\section{Ischemic ulcers}

Peripheral arterial disease (PAD) may result in severe ischemia. ${ }^{[92]}$ Reduce tissue perfusion due to ischemia results in progressive tissue hypoxia, ischemia, necrosis and skin breakdown. In theory, tissue hypoxia should 
initiate angiogenesis via inducing an HIF-1 $\alpha$ and angiogenic growth factors. In patients with PAD, serum levels of hepatocyte growth factor are elevated than in normal subjects. ${ }^{[93]}$ The tissue compromise caused by severe macrovascular disease, however, may over dominate the angiogenic response. Inter-individual differences in the ability to mount angiogenesis under hypoxic conditions also exist among patients with atherosclerosis. Such variations may explain that patients with PAD are unable to generate adequate collateral circulation and unable to heal arterial ulcers despite surgical bypass. Therapeutic growth factors or other methods designed to stimulate angiogenesis might benefit patients with a defective angiogenic capacity. VEGF gene transfer ${ }^{[94]}$ or autologous transplantation of bone marrow-derived endothelial progenitor stem cells ${ }^{[95]}$ improved healing of arterial ulcers in patients.

\section{ANGIOMODULATORY STRATEGIES}

Wound angiogenesis represents a realistic model to study molecular mechanisms involved in the formation and remodeling of vascular structures. In particular, the repair of skin defect offers an ideal model to analyze angiogenesis as it is easy to control and manipulate this process. ${ }^{[96]}$ Vessel growth is controlled by the local actions of chemical mediators, the ECM, metabolic gradients and physical forces. Manipulation of some of these factors is being tried to improve healing in experimental wounds. ${ }^{[97]}$ Scientists are working on mathematical models which describe the role of angiogenesis as observed during (soft tissue) wound healing. Through this model manipulation of the capillary tip, macrophage-derived chemical attractant profile, extracellular matrix and fibroblast diffusion coefficient may be analyzed to enhance wound healing. ${ }^{\text {[98] }}$

\section{CONCLUSION}

Angiogenesis is a physiological process that is vital for normal wound healing. A number of factors regulate wound angiogenesis, including hypoxia, inflammation and growth factors. The molecular and cellular events in angiogenesis have been elucidated, and defects in this process are present in chronic wounds. Based on this knowledge, new wound healing strategies are emerging to deliver growth factors to the wound bed. Surgeons and other wound-care specialists can use this knowledge to identify defects and select interventions that may promote improved wound granulation and healing.

\section{Financial support and sponsorship} Nil.

\section{Conflicts of interest}

There are no conflicts of interest.

\section{REFERENCES}

I. Li WW, Li VW, Tsakayannis D. Angiogenesis therapies. Concepts, clinical trials, and considerations for new drug development. In: Fan TPD, Kohn EC, editors. The New Angiotherapy. Totowa: Humana Press; 2002. p. 547-7I.
2. Folkman J. Seminars in medicine of the Beth Israel hospital, Boston. Clinical applications of research on angiogenesis. N Engl J Med 1995;333: I 757-63.

3. Valko M, Leibfritz D, Moncol J, Cronin MT, Mazur M, Telser J. Free radicals and antioxidants in normal physiological functions and human disease. Int J Biochem Cell Biol 2007;39:44-84.

4. Rees M, Hague S, Oehler MK, Bicknell R. Regulation of endometrial angiogenesis. Climacteric 1999;2:52-8.

5. Tonnesen MG, Feng X, Clark RA. Angiogenesis in wound healing. J Investig Dermatol Symp Proc 2000;5:40-6.

6. Shah F, Balan P, Weinberg M, Reddy V, Neems R, Feinstein M, Dainauskas J, Meyer P, Goldin M, Feinstein SB. Contrast-enhanced ultrasound imaging of atherosclerotic carotid plaque neovascularization: a new surrogate marker of atherosclerosis? Vasc Med 2007; 12:291-7.

7. Folkman J. Angiogenesis. In: Braunwald E, Fauci AS, Kasper DL, Hauser SL, Longo DL, Jameson LJ, editors. Harrison's Textbook of Internal Medicine. I5th ed. New York: McGraw-Hill; 200I. p. 5I7-30.

8. O'Connor DS, Schechner JS, Adida C, Mesri M, Rothermel AL, Li F, Nath AK, Pober JS, Altieri DC. Control of apoptosis during angiogenesis by survivin expression in endothelial cells. Am J Pathol 2000;156:393-8.

9. Clark RA. Wound repair. Overview and general considerations. In: Clark RAF, editor. The Molecular and Cellular Biology of Wound Repair. New York: Plenum; 1996. p. 3-50.

10. Morgan MR, Humphries MJ, Bass MD. Synergistic control of cell adhesion by integrins and syndecans. Nat Rev Mol Cell Biol 2007;8:957-69.

II. Semenza G. Signal transduction to hypoxia-inducible factor I. Biochem Pharmacol 2002;64:993-8.

12. Majima M, Hayashi I, Muramatsu M, Katada J, Yamashina S, Katori M. Cyclo-oxygenase-2 enhances basic fibroblast growth factor-induced angiogenesis through induction of vascular endothelial growth factor in rat sponge implants. BrJ Pharmacol 2000;130:64I-9.

13. Pugh CW, Ratcliffe PJ. Regulation of angiogenesis by hypoxia: role of the HIF system. Nat Med 2003;9:677-84.

14. Miles KA. Perfusion CT for the assessment of tumour vascularity: which protocol? Br J Radiol 2003;76:S36-42.

15. Hanahan D, Weinberg RA. Hallmarks of cancer: the next generation. Cell 20I I; |44:646-74

16. Matsuoka H, Sisson TH, Nishiuma T, Simon RH. Plasminogen-mediated activation and release of hepatocyte growth factor from extracellular matrix. Am J Respir Cell Mol Biol 2006;35:705-I3.

17. Tsopanoglou NE, Maragoudakis ME. On the mechanism of thrombin-induced angiogenesis. Potentiation of vascular endothelial growth factor activity on endothelial cells by up-regulation of its receptors. J Biol Chem 1999;274:23969-76.

18. Nguyen M, Arkell J, Jackson CJ. Human endothelial gelatinases and angiogenesis. Int J Biochem Cell Biol 200I;33:960-70.

19. Hellberg C, Ostman A, Heldin CH. PDGF and vessel maturation. Recent Results Cancer Res 2010;180:103-14.

20. Pintucci G, Froum S, Pinnell J, Mignatti P, Rafii S, Green D. Trophic effects of platelets on cultured endothelial cells are mediated by platelet-associated fibroblast growth factor-2 (FGF-2) and vascular endothelial growth factor (VEGF). Thromb Haemost 2002;88:834-42.

21. Li JJ, Huang YQ, Basch R, Karpatkin S. Thrombin induces the release of angiopoietin-I from platelets. Thromb Haemost 200 I;85:204-6.

22. Nath SG, Raveendran R. An insight into the possibilities of fibroblast growth factor in periodontal regeneration. J Indian Soc Periodontol 20।4; I8:289-92.

23. Yoshida S, Yoshida A, Matsui H, Takada Y, Ishibashi T. Involvement of macrophage chemotactic protein-I and interleukin-I beta during inflammatory but not basic fibroblast growth factor-dependent neovascularization in the mouse cornea. Lab Invest 2003;83:927-38.

24. Grimm D, Bauer J, Schoenberger J. Blockade of neoangiogenesis, a new and promising technique to control the growth of malignant tumors and their metastases. Curr Vasc Pharmacol 2009;7:347-57.

25. Lutolf MP, Hubbell JA. Synthetic biomaterials as instructive extracellular microenvironments for morphogenesis in tissue engineering. Nat Biotechnol 2005;23:47-55.

26. Bootle-Wilbraham CA, Tazzyman S, Thompson WD, Stirk CM, Lewis CE. Fibrin fragment $E$ stimulates the proliferation, migration and differentiation of human microvascular endothelial cells in vitro. Angiogenesis 200I;4:269-75

27. Ji K, Tsirka SE. Inflammation modulates expression of laminin in the central nervous system following ischemic injury. J Neuroinflammation 2012;9:159.

28. Acker $\mathrm{T}$, Plate $\mathrm{KH}$. Role of hypoxia in tumor angiogenesis-molecular and cellular angiogenic crosstalk. Cell Tissue Res 2003;3।4: I45-55.

29. Howdieshell TR, Webb WL, Sathyanarayana, McNeil PL. Inhibition of 
inducible nitric oxide synthase results in reductions in wound vascular endothelial growth factor expression, granulation tissue formation, and local perfusion. Surgery 2003;133:528-37.

30. Leonardi R, Caltabiano M, Pagano M, Pezzuto V, Loreto C, Palestro G. Detection of vascular endothelial growth factor/vascular permeability factor in periapical lesions. J Endod 2003;29:180-3.

31. Smith RS Jr, Gao L, Bledsoe G, Chao L, Chao J. Intermedin is a new angiogenic growth factor. Am J Physiol Heart Circ Physiol 2009;297:HI040-7.

32. Inoki I, Shiomi T, Hashimoto G, Enomoto H, Nakamura H, Makino K, Ikeda E, Takata S, Kobayashi K, Okada Y. Connective tissue growth factor binds vascular endothelial growth factor (VEGF) and inhibits VEGF-induced angiogenesis. FASEB J 2002;16:219-21.

33. Ma J, Wang Q, Fei T, Han JD, Chen YG. MCP-I mediates TGF-beta-induced angiogenesis by stimulating vascular smooth muscle cell migration. Blood 2007; 109:987-94

34. Korff T, Kimmina S, Martiny-Baron G, Augustin HG. Blood vessel maturation in a 3-dimensional spheroidal coculture model: direct contact with smooth muscle cells regulates endothelial cell quiescence and abrogates VEGF responsiveness. FASEB / 200I;15:447-57.

35. Onimaru M, Yonemitsu Y, Fujii T, Tanii M, Nakano T, Nakagawa K, Kohno R, Hasegawa M, Nishikawa S, Sueishi K. VEGF-C regulates lymphangiogenesis and capillary stability by regulation of PDGF-B. Am J Physiol Heart Circ Physiol 2009;297:HI685-96.

36. Kumar I, Staton CA, Cross SS, Reed MW, Brown NJ. Angiogenesis, vascular endothelial growth factor and its receptors in human surgical wounds. Br J Surg 2009;96:|484-9|.

37. Darland DC, D'Amore PA. TGF beta is required for the formation of capillary-like structures in three-dimensional cocultures of 10TI/2 and endothelial cells. Angiogenesis 200 I;4: I I-20.

38. McCarty MF, Bielenberg DR, Nilsson MB, Gershenwald JE, Barnhill RL, Ahearne P, Bucana CD, Fidler IJ. Epidermal hyperplasia overlying human melanoma correlates with tumour depth and angiogenesis. Melanoma Res 2003; 13:379-87.

39. Michaels J 5th, Dobryansky M, Galiano RD, Bhatt KA, Ashinoff R, Ceradini DJ, Gurtner GC. Topical vascular endothelial growth factor reverses delayed wound healing secondary to angiogenesis inhibitor administration. Wound Repair Regen 2005; 13:506-12.

40. Lange-Asschenfeldt B, Velasco P, Streit M, Hawighorst T, Pike SE, Tosato G, Detmar M. The angiogenesis inhibitor vasostatin does not impair wound healing at tumor-inhibiting doses. J Invest Dermatol 200 I; I 7:1036-4I.

41. Van der Bilt JD, Borel Rinkes IH. Surgery and angiogenesis. Biochim Biophys Acto 2004; 1654:95-104

42. Hiromatsu $\mathrm{Y}$, Toda S. Mast cells and angiogenesis. Microsc Res Tech 2003;60:64-9.

43. Ornitz DM, Itoh N. Fibroblast growth factors. Genome Biol 200।;2:REVIEWS3005.

44. Barrientos S, Stojadinovic O, Golinko MS, Brem H, Tomic-Canic M. Growth factors and cytokines in wound healing. Wound Repair Regen 2008; 16:585-60 I.

45. Plum SM, Vu HA, Mercer B, Fogler WE, Fortier AH. Generation of a specific immunological response to FGF-2 does not affect wound healing or reproduction. Immunopharmacol Immunotoxicol 2004;26:29-4I.

46. Nagy JA, Benjamin L, Zeng H, Dvorak AM, Dvorak HF. Vascular permeability, vascular hyperpermeability and angiogenesis. Angiogenesis 2008; II:109-19.

47. Breier G, Blum S, Peli J, Groot M, Wild C, Risau W, Reichmann E. Transforming growth factor-beta and Ras regulate the VEGF/VEGF-receptor system during tumor angiogenesis. Int J Cancer 2002;97:I42-8.

48. Bates DO, Heald RI, Curry FE, Williams B. Vascular endothelial growth factor increases Rana vascular permeability and compliance by different signalling pathways. J Physiol 200 I;533:263-72.

49. Failla CM, Odorisio T, Cianfarani F, Schietroma C, Puddu P, Zambruno G. Placenta growth factor is induced in human keratinocytes during wound healing. J Invest Dermatol 2000; I I 5:388-95.

50. Hemmerlein B, Kugler A, Ozisik R, Ringert RH, Radzun HJ, Thelen P. Vascular endothelial growth factor expression, angiogenesis, and necrosis in renal cell carcinomas. Virchows Arch 2001;439:645-52

5I. Zachary I, Gliki G. Signaling transduction mechanisms mediating biological actions of the vascular endothelial growth factor family. Cardiovasc Res 200I;49:568-8I.

52. Efron PA, Moldawer LL. Cytokines and wound healing: the role of cytokine and anticytokine therapy in the repair response. J Burn Care Rehabil 2004;25:149-60.

53. Ferrara N, Gerber HP, LeCouter J. The biology of VEGF and its receptors. Nat Med 2003;9:669-76.
54. Bates DO, Harper SJ. Regulation of vascular permeability by vascular endothelial growth factors. Vascul Pharmacol 2002;39:225-37.

55. Ferrara N. Vascular endothelial growth factor: basic science and clinical progress. Endocr Rev 2004;25:58I-6II.

56. Kessler T, Fehrmann F, Bieker R, Berdel WE, Mesters RM. Vascular endothelial growth factor and its receptor as drug targets in hematological malignancies. Curr Drug Targets 2007;8:257-68.

57. Roth D, Piekarek M, Paulsson M, Christ H, Bloch W, Krieg T, Davidson JM, Eming SA. Plasmin modulates vascular endothelial growth factor-A-mediated angiogenesis during wound repair. Am J Pathol 2006; 168:670-84.

58. Primo L, Seano G, Roca C, Maione F, Gagliardi PA, Sessa R, Martinelli M, Giraudo E, di Blasio L, Bussolino F. Increased expression of alpha6 integrin in endothelial cells unveils a proangiogenic role for basement membrane. Cancer Res 2010;70:5759-69.

59. Rao X, Zhong J, Zhang S, Zhang Y, Yu Q, Yang P, Wang MH, Fulton DJ, Shi H, Dong Z, Wang D, Wang CY. Loss of methyl-CpG-binding domain protein 2 enhances endothelial angiogenesis and protects mice against hind-limb ischemic injury. Circulation 201 I;123:2964-74.

60. Brunner G, Blakytny R. Extracellular regulation of TGF-beta activity in wound repair: growth factor latency as a sensor mechanism for injury. Thromb Haemost 2004;92:253-6I.

6I. Verrecchia F, Mauviel A. Transforming growth factor-beta and fibrosis. World J Gastroenterol 2007; I3:3056-62.

62. Tsigkos S, Koutsilieris M, Papapetropoulos A. Angiopoietins in angiogenesis and beyond. Expert Opin Investig Drugs 2003; I2:933-4I.

63. Solovyan VT, Keski-Oja J. Apoptosis of human endothelial cells is accompanied by proteolytic processing of latent TGF-beta binding proteins and activation of TGF-beta. Cell Death Differ 2005; I2:8I5-26.

64. Iddamalgoda A, Le QT, Ito K, Tanaka K, Kojima H, Kido H. Mast cell tryptase and photoaging: possible involvement in the degradation of extra cellular matrix and basement membrane proteins. Arch Dermatol Res 2008;300 Suppl I:S69-76.

65. Martin A, Komada MR, Sane DC. Abnormal angiogenesis in diabetes mellitus. Med Res Rev 2003;23: I 17-45.

66. Brem H, Jacobs T, Vileikyte L, Weinberger S, Gibber M, Gill K, Tarnovskaya A, Entero H, Boulton AJ. Wound-healing protocols for diabetic foot and pressure ulcers. Surg Technol Int 2003; I I:85-92.

67. Keswani SG, Katz AB, Lim FY, Zoltick P, Radu A, Alaee D, Herlyn M, Crombleholme TM.Adenoviral mediated gene transfer of PDGF-B enhances wound healing in type I and type II diabetic wounds. Wound Repair Regen 2004; 12:497-504

68. Altavilla D, Saitta A, Cucinotta D, Galeano M, Deodato B, Colonna M, Torre V, Russo G, Sardella A, Urna G, Campo GM, Cavallari V, Squadrito G, Squadrito F. Inhibition of lipid peroxidation restores impaired vascular endothelial growth factor expression and stimulates wound healing and angiogenesis in the genetically diabetic mouse. Diabetes 200I;50:667-74

69. Wicke C, Halliday B, Allen D, Roche NS, Scheuenstuhl H, Spencer MM, Roberts $A B$, Hunt TK. Effects of steroids and retinoids on wound healing. Arch Surg 2000; I35: I 265-70.

70. Peplow PV, Baxter GD. Gene expression and release of growth factors during delayed wound healing: a review of studies in diabetic animals and possible combined laser phototherapy and growth factor treatment to enhance healing. Photomed Laser Surg 2012;30:6I7-36.

7I. Stavrou D. Neovascularisation in wound healing. J Wound Care 2008; 17:298-300, 2

72. Johnson KE, Wilgus TA. Vascular endothelial growth factor and angiogenesis in the regulation of cutaneous wound repair. Adv Wound Care (New Rochelle) 20I4;3:647-6I.

73. Hoffman M, Monroe DM. Wound healing in haemophilia-breaking the vicious cycle. Haemophilia 2010;16 Suppl 3:13-8.

74. Goova MT, Li J, Kislinger T, Qu W, Lu Y, Bucciarelli LG, Nowygrod S, Wolf BM, Caliste X, Yan SF, Stern DM, Schmidt AM. Blockade of receptor for advanced glycation end-products restores effective wound healing in diabetic mice. Am J Pathol 200 I; 159:5 I3-25.

75. Corral CJ, Siddiqui A, Wu L, Farrell CL, Lyons D, Mustoe TA. Vascular endothelial growth factor is more important than basic fibroblastic growth factor during ischemic wound healing. Arch Surg 1999; 134:200-5.

76. Howdieshell TR, Callaway D, Webb WL, Gaines MD, Procter CD Jr, Sathyanarayana, Pollock JS, Brock TL, McNeil PL. Antibody neutralization of vascular endothelial growth factor inhibits wound granulation tissue formation. J Surg Res 2001;96:173-82.

77. Lerman OZ, Galiano RD, Armour M, Levine JP, Gurtner GC. Cellular dysfunction in the diabetic fibroblast: impairment in migration, vascular 
endothelial growth factor production, and response to hypoxia. Am J Pathol 2003;162:303-12.

78. Galiano RD, Tepper OM, Pelo CR, Bhatt KA, Callaghan M, Bastidas N, Bunting S, Steinmetz HG, Gurtner GC. Topical vascular endothelial growth factor accelerates diabetic wound healing through increased angiogenesis and by mobilizing and recruiting bone marrow-derived cells. Am J Pathol 2004;164:1935-47.

79. Weinheimer-Haus EM, Judex S, Ennis WJ, Koh TJ. Low-intensity vibration improves angiogenesis and wound healing in diabetic mice. PLoS One 2014;9:e91355.

80. Franzeck UK, Haselbach P, Speiser D, Bollinger A. Microangiopathy of cutaneous blood and lymphatic capillaries in chronic venous insufficiency (CVI). Yale J Biol Med 1993;66:37-46.

81. Jünger M, Steins $A$, Hahn M, Häfner HM. Microcirculatory dysfunction in chronic venous insufficiency (CVI). Microcirculation 2000;7:S3-12.

82. Shoab SS, Scurr JH, Coleridge-Smith PD. Plasma VEGF as a marker of therapy in patients with chronic venous disease treated with oral micronised flavonoid fraction-a pilot study. Eur J Vasc Endovasc Surg 1999; 18:334-8.

83. Oahues N, Philips TJ. Leg ulcers. Curr Probl Dermatol 1995;7:109-42.

84. Moosa HH, Falanga V, Steed DL, Makaroun MS, Peitzman AB, Eaglstein WH, Webster MW. Oxygen diffusion in chronic venous ulceration. J Cardiovasc Surg (Torino) 1987;28:464-7.

85. Falanga $\mathrm{V}$, Moosa HH, Nemeth AJ, Alstadt SP, Eaglstein WH. Dermal pericapillary fibrin in venous disease and venous ulceration. Arch Dermatol 1987;123:620-3.

86. Weckroth M, Vaheri A, Virolainen S, Saarialho-Kere U, Jahkola $T$, Sirén V. Epithelial tissue-type plasminogen activator expression, unlike that of urokinase, its receptor, and plasminogen activator inhibitor-I, is increased in chronic venous ulcers. Br J Dermatol 2004;151:1 189-96.

87. Higley HR, Ksander GA, Gerhardt CO, Falanga V. Extravasation of macromolecules and possible trapping of transforming growth factor-beta in venous ulceration. Br J Dermatol 1995; 132:79-85.

88. Trent JT, Falabella A, Eaglstein WH, Kirsner RS. Venous ulcers: pathophysiology and treatment options. Ostomy Wound Manage 2005;51:38-54.
89. Lyseng-Williamson KA, Perry CM. Micronised purified flavonoid fraction: a review of its use in chronic venous insufficiency, venous ulcers and haemorrhoids. Drugs 2003;63:71-100.

90. Sundberg C, Nagy JA, Brown LF, Feng D, Eckelhoefer IA, Manseau EJ, Dvorak AM, Dvorak HF. Glomeruloid microvascular proliferation follows adenoviral vascular permeability factor/vascular endothelial growth factor-164 gene delivery. Am J Pathol 200 I; I58: I I45-60.

91. McCarty SM, Cochrane CA, Clegg PD, Percival SL. The role of endogenous and exogenous enzymes in chronic wounds: a focus on the implications of aberrant levels of both host and bacterial proteases in wound healing. Wound Repair Regen 2012;20:125-36.

92. Weitz JI, Byrne J, Clagett GP, Farkouh ME, Porter JM, Sackett DL, Strandness DE Jr, Taylor LM. Diagnosis and treatment of chronic arterial insufficiency of the lower extremities: a critical review. Circulation 1996;94:3026-49.

93. Konya H, Miuchi M, Satani K, Matsutani S, Tsunoda T, Yano Y, Katsuno T, Hamaguchi T, Miyagawa J, Namba M. Hepatocyte growth factor, a biomarker of macroangiopathy in diabetes mellitus. World J Diabetes 2014;5:678-88.

94. Baumgartner I, Pieczek A, Manor O, Blair R, Kearney M, Walsh K, Isner JM. Constitutive expression of phVEGFI65 after intramuscular gene transfer promotes collateral vessel development in patients with critical limb ischemia. Circulation 1998;97: | | |4-23.

95. Lawall H, Bramlage P, Amann B. Stem cell and progenitor cell therapy in peripheral artery disease. A critical appraisal. Thromb Haemost 2010;103:696-709.

96. Eming SA, Brachvogel B, Odorisio T, Koch M. Regulation of angiogenesis: wound healing as a model. Prog Histochem Cytochem 2007;42:I I5-70.

97. Bauer SM, Bauer RJ, Velazquez OC. Angiogenesis, vasculogenesis, and induction of healing in chronic wounds. Vasc Endovascular Surg 2005;39:293-306.

98. Chaplain M, Anderson A. Mathematical modelling of tumour-induced angiogenesis: network growth and structure. Cancer Treat Res 2004; | 17:5 I-75. 